\title{
Basic fibroblast growth factor upregulates survivin expression in hepatocellular carcinoma cells via a protein kinase B-dependent pathway
}

\author{
BO SUN ${ }^{1,2^{*}}$, HAIYAN XU ${ }^{3 *}$, GANG ZHANG $^{4}$, YONGBAO ZHU $^{2}$, HUKUI SUN $^{1}$ and GUIHUA HOU ${ }^{1}$ \\ ${ }^{1}$ Institute of Experimental Nuclear Medicine, School of Medicine, Shandong University, Jinan, Shandong; \\ ${ }^{2}$ The Blood Center of Shandong Province, Jinan, Shandong; ${ }^{3}$ Affiliated Hospital of Tianjin Academy of \\ Traditional Chinese Medicine, Tianjin; ${ }^{4}$ The First People's Hospital of Zibo City, Shandong, P.R. China
}

Received January 16, 2013; Accepted March 21, 2013

DOI: $10.3892 /$ or.2013.2479

\begin{abstract}
Basic fibroblast growth factor (bFGF) plays an important role in tumor angiogenesis. Several studies have reported that bFGF may influence cell apoptosis through different signaling pathways. The aim of the present investigation was to study the effect of bFGF on the activities of protein kinase B (PKB)/survivin and cell apoptosis in hepatocellular carcinoma cells (Bel-7402). We treated Bel-7402 cells with bFGF and wortmannin [phosphatidylinositol 3-kinase (PI3K)specific inhibitor] separately to observe the expression of $\mathrm{PKB}$ and survivin detected with RT-PCR and western blotting. The cell cycle and apoptosis were assayed with flow cytometry. We found a significant increase in PKB expression in the group treated with $25 \mathrm{ng} / \mathrm{ml} \mathrm{bFGF}$ for $10 \mathrm{~min}(\mathrm{P}<0.05)$, and this effect was significantly inhibited by pretreatment with wortmannin (200 $\mathrm{nM}$ ) for $1 \mathrm{~h}$. After treatment with $10 \mathrm{ng} / \mathrm{ml} \mathrm{bFGF}$, the expression of survivin mRNA in Bel-7402 cells increased significantly, and reached the peak at $16 \mathrm{~h}(\mathrm{P}<0.05)$; however, this effect could be significantly inhibited by pretreatment with wortmannin $(200 \mathrm{mM})$ in a time-dependent manner. Following incubation with $25 \mathrm{ng} / \mathrm{ml} \mathrm{bFGF}$ for $10 \mathrm{~min}$, the apoptosis rate and $\mathrm{M}$ phase were significantly decreased and $\mathrm{S}$ phase cells increased compared with the wortmannin (200 nM)-treated group. When this group was pretreated with wortmannin (200 $\mathrm{nM}$ ) for $1 \mathrm{~h}$, the apoptosis rate and $\mathrm{S}$ phase were significantly increased, $M$ phase cells decreased. The results revealed that wortmannin could induce high apoptosis rates in hepatocellular carcinoma cells, and bFGF could inhibit the cell apoptosis induced by wortmannin. These findings indicate that bFGF could rapidly activate the PKB activities, enhance the
\end{abstract}

Correspondence to: Professor Guihua Hou, Key Laboratory for Experimental Teratology of the Ministry of Education and Institute of Experimental Nuclear Medicine, School of Medicine, Shandong University, 44 Wenhua Xi Road, Jinan, Shandong 250012, P.R. China E-mail: ghhou1@hotmail.com

*Contributed equally

Key words: basic fibroblast growth factor, protein kinase B, survivin, wortmannin, hepatocarcinoma expression of survivin and the proliferation of hepatocellular carcinoma cells via the PI3K pathway, thus it may serve as a novel molecule for early targeting therapy of hepatocellular carcinoma.

\section{Introduction}

Liver cancer is one of the most malignant diseases. The early diagnosis and treatment will greatly improve patient prognosis. In recent years, there has been a growing awareness that the cellular microenvironment during tumorigenesis plays a critical role in cancer cell proliferation, survival, migration and invasion (1-3). Substantial evidence shows that cancer is the result of imbalance of endogenous angiogenesis inhibitor and accelerator local concentrations in the tumor tissue. The most important angiogenesis promoting agent is basic fibroblast growth factor (bFGF) and vascular growth factor (VEGF) $(4,5)$. Several recent reports have also implicated bFGF as a major survival factor, which has been shown to mediate this additional function through the induction of Bcl-2 and the activation of the PI3 kinase-Akt/ protein kinase $\mathrm{B}(\mathrm{PKB})$ signaling pathway. bFGF can also mediate the induction/upregulation of members of a newly discovered family of antiapoptotic proteins, i.e., the inhibitors of apoptosis (IAP) in vascular endothelial cells $(6,7)$. PKB is an enzyme that covalently attaches ATP-phosphate groups to the serine/threonine on protein substrates to alter the activity of the targeted protein $(8,9)$. The activation of Akt is initiated with the plasma membrane recruitment of phosphatidylinositol 3-kinase (PI3K), an upstream enzyme stimulated by a variety of activated growth factor receptors such as epidermal growth factor receptor (EGFR), vascular growth factor receptor (VEGFR), bFGF, and insulin-like growth factor receptor (IGFR) (10). The activation of Akt is completed via the phosphorylation of Thr-308 and Ser-473, leading to increased Akt activity toward a variety of downstream substrates, such as the family of forkhead transcription factors for inhibiting tumor proliferation, the mammalian target of rapamycin (mTOR) for modulating protein synthesis, and the $\mathrm{Bcl}-\mathrm{xL} / \mathrm{Bcl}-2$-associated death promoter (BAD) for uncontrolled proliferation $(9,11)$. Since Akt acts as a signal hub in the regulation of cell survival, 
proliferation and growth, the elevation in Akt activity is found to be correlated with increased tumorigenicity (8). Thus, a variety of inhibitors targeting Akt or its up- or downstream events are currently under clinical trials (12). Wortmannin is a potent and selective inhibitor of Akt, and molecular imaging of Akt activity has become an important approach in monitoring Akt activity in vivo. Numerous studies have confirmed that PI3K/PKB plays a crucial role in promoting proliferation and inhibiting apoptosis (13-16).

Survivin is the smallest protein of the known IAP family (17). It is a unique bifunctional protein that inhibits apoptosis by suppressing caspase- 3 and caspase- 7 and modulates the $\mathrm{G} 2 / \mathrm{M}$ phase of the cell cycle through association with mitotic spindle microtubules (18). Survivin contains a single BIR domain and can bind caspases, preventing caspaseinduced apoptosis (19); it is the least-expressed IAP family candidate in adult tissues (almost absent in normal tissue), but can be recognized in developing fetal tissues, with the exception of placenta and thymus (20-23). Survivin is able to inhibit apoptosis and promote proliferation of tumor cells. Recently, it was found that survivin protein degradation is associated with the disorder of pantothenic acid - proteasome pathway in a cell cycle-dependent manner (24). The potential value of survivin in tumor diagnosis and treatment has gained considerable attention. It is possible to inhibit growth and recurrence of liver cancer through inhibiting the expression of survivin. Survivin is the strongest inhibitor of apoptosis and its regulation and signaling pathway has yet to be fully clarified. It was reported that bFGF and its receptor FGFR1 highly expressed in hepatocarcinoma cells, play an important role in the occurrence and development of liver cancer and promote the growth of liver cancer cells by autocrine or paracrine mechanisms (25). Investigations into the FGF/FGFR signal pathway may reveal the pathogenesis of numerous diseases, and it may become a new target for the treatment of liver cancer and other diseases. In the present study, we examined whether bFGF could regulate the expression of survivin and affect the apoptosis of liver cancer cells, and we elucidated its signal pathway so as to provide a basis for bFGF in regulating apoptosis via the PI3K/ PKB pathway in the treatment of liver cancer.

\section{Materials and methods}

Cells lines and culture. Human hepatocarcinoma cell line Bel-7402 (Shanghai Institute of Cell Biology, Chinese Academy of Sciences) was maintained in DMEM medium supplemented with 10\% fetal calf serum (Hangzhou Sijiqing Biological Engineering Materials Co., Ltd., China), $100 \mathrm{U} / \mathrm{ml}$ penicillin and $100 \mu \mathrm{g} / \mathrm{ml}$ streptomycin (Gibco) in $5 \% \mathrm{CO}_{2}$ at $37^{\circ} \mathrm{C}$. Bel-7402 cells were exposed to bFGF (Beijing Shuanglu Pharmaceutical Co., Ltd., China) at different concentrations $(0,12.5,25,50$ and $75 \mathrm{ng} / \mathrm{ml})$ for $10 \mathrm{~min}$, or to $25 \mathrm{ng} / \mathrm{ml} \mathrm{bFGF}$ at different times $(0,5,10,30$ and $60 \mathrm{~min})$ respectively. Each group had 3 parallel wells. Wortmannin (Sigma) was dissolved in dimethyl sulfoxide (DMSO) in serum-free medium with a final concentration of 100, 200 and $400 \mathrm{nM}$.

Western blot analysis. Cultured cells were harvested, washed with phosphate-buffered saline (PBS), and resuspended in lysis buffer $(20 \mathrm{mM}$ Tris- $\mathrm{HCl}, \mathrm{pH} 7.5$, containing $1 \%$
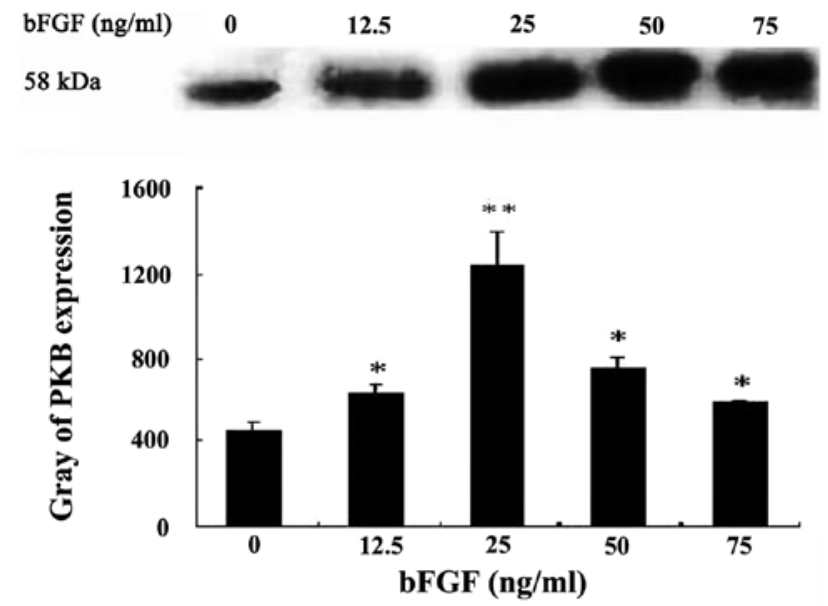

Figure 1. PKB activity of Bel-7402 cells at different concentrations of bFGF $(\mathrm{n}=3$, mean $\pm \mathrm{SD}) .{ }^{*}$ Compared with the control group, $\mathrm{P}<0.05 .{ }^{* *}$ Compared with the control group, $\mathrm{P}<0.01$.

SDS (sodium dodecyl sulfate), $50 \mathrm{mM} \mathrm{NaCl}, 1 \mathrm{mM}$ EDTA (ethylenediaminetetraacetic acid), $1 \mathrm{mM}$ PMSF (phenylmethylsulfonyl fluoride), $10 \mathrm{mM}$ sodium fluoride, and $1 \mathrm{mM}$ sodium orthovanadate. Cell samples were then agitated at $4^{\circ} \mathrm{C}$ for $1 \mathrm{~h}$ followed by centrifugation for $15 \mathrm{~min}$. Equivalent amounts of protein $(40 \mu \mathrm{g})$ from each sample were separated on $10 \%$ SDS-PAGE (polyacrylamide gel electrophoresis) and the separated proteins were transferred to nitrocellulose membranes. Membranes were routinely blocked in 5\% nonfat milk in PBS with $0.1 \%$ Tween-20 for an hour with agitation and washed, and primary antibodies PKB (Santa Cruz Biotechnology, Inc., Santa Cruz, CA, USA) or survivin were added (1:5001,000 dilution in 5\% bovine serum albumin in PBS buffer). Membranes were incubated overnight at $4^{\circ} \mathrm{C}$ with agitation, washed, and then incubated with horseradish peroxidaseconjugated secondary antibodies (1:5,000 dilutions in 5\% bovine serum albumin in PBS with $0.1 \%$ Tween-20) for $3 \mathrm{~h}$ at room temperature. Proteins were detected using the Enhanced Chemiluminescence Western Blotting Detection Reagent (Pierce, Rockford, IL, USA). The results were described as a ratio of relative absorbance value of the protein band of interest to $\beta$-actin.

RNA extraction and RT-PCR. Total RNA was extracted, reverse transcribed, amplified and analyzed as previously described (26). Briefly, total RNA was extracted from Bel-7402 cells using a total RNA isolation kit (TransGen) according to the manufacturer's protocol. An ultraviolet spectrophotometer was used to determine the quantity and quality of total RNA. $\beta$-actin was used to normalize cDNA quantities and was amplified with the following primers: forward, 5'-ATCATGTTT GAGACCTTCAACA-3' and reverse, 5'-CATCTCTTGCTC GAAGTCCA-3'. For survivin, the following primers were used: forward, 5'-GCACTTTCTTCGCAGTTTCC-3' and reverse, 5'-GGACCACCGCATCTCTACAT-3' (Biosune). The PCR reaction was carried out under the following conditions: 35 cycles of denaturation at $94^{\circ} \mathrm{C}$ for $1 \mathrm{~min}$, annealing at $55^{\circ} \mathrm{C}$ for $1 \mathrm{~min}$, and an extension at $72^{\circ} \mathrm{C}$ for $2 \mathrm{~min}$. A final extension was performed at $72^{\circ} \mathrm{C}$ for $1 \mathrm{~min}$. PCR products were separated by $1 \%$ agarose gel electrophoresis. 


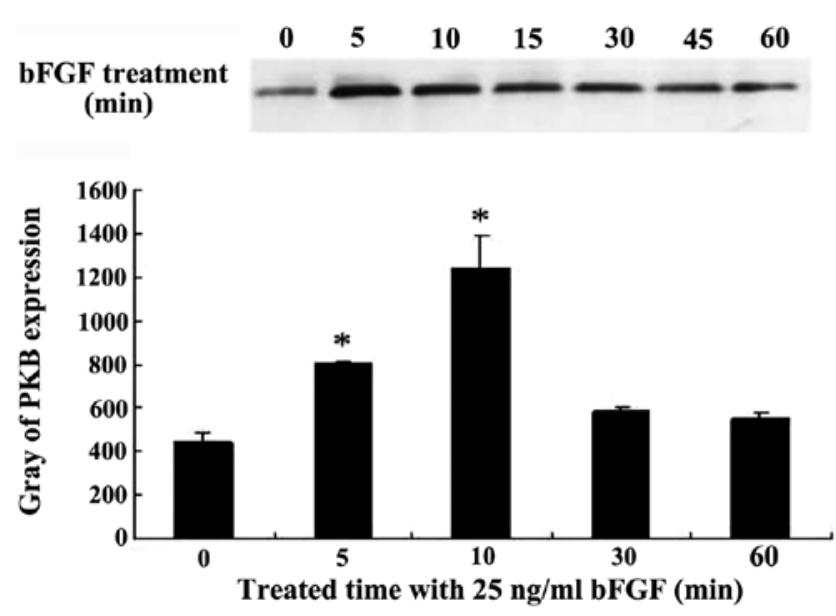

Figure 2. PKB activity of Bel-7402 cells after treatment with bFGF at different times. ${ }^{*}$ Compared with the control group, $\mathrm{P}<0.05(\mathrm{n}=3$, mean \pm SD).

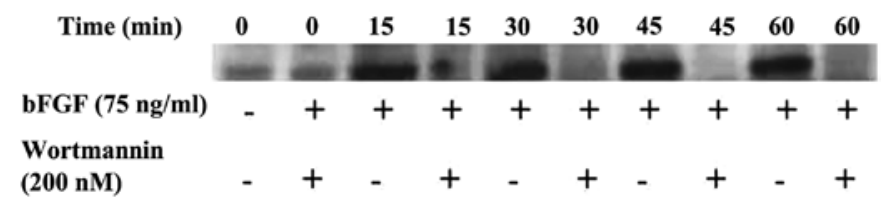

Figure 3. PKB activity in hepatoma cells after bFGF stimulation and pretreatment with wortmannin.

Cell-cycle and apoptosis assay. Bel-7402 cells were treated with different concentrations of bFGF for different times in serum-free medium. Following incubation, cells were harvested, washed in PBS, fixed in cold 70\% ethanol for $45 \mathrm{~min}$, stained with propidium iodide solution that contains RNase A for $30 \mathrm{~min}$, and analyzed by flow cytometry (BD Biosciences, San Jose, CA, USA). CellQuest analysis software was used for DNA content analysis of the cell cycle.

Statistical analysis. All values were expressed as means \pm SD. Statistical analysis was processed using one-way ANOVA. $\mathrm{P}<0.05$ was considered to indicate a statistically significant difference.

\section{Results}

$P K B$ activity increases in hepatocarcinoma cells following bFGF treatment. The cytosolic PKB activity gradually increased with bFGF $0-25 \mathrm{ng} / \mathrm{ml}$ following different concentrations of bFGF co-incubated with Bel-7402 cells for $10 \mathrm{~min}$, and reached the highest value at $25 \mathrm{ng} / \mathrm{ml}, 2.81$-fold of control $(\mathrm{P}<0.01)$; then, cytosol PKB activity declined. There was a significant difference of PKB expression between the bFGFtreated and -untreated groups $(\mathrm{P}<0.05)$ (Fig. 1). Bel-7402 cells were co-incubated with $25 \mathrm{ng} / \mathrm{ml}$ bFGF for $5,10,30$ and $60 \mathrm{~min}$. The PKB cytosol activity began to increase at $5 \mathrm{~min}, 1.82$-fold for the control group, and it increased the most at 10 min, which was 2.81-fold that of the control group, and subsequently PKB activity began to decline at $60 \mathrm{~min}$. There was a statistically significant difference $(\mathrm{P}<0.05)$ (Fig. 2). Western blot analysis showed that PKB expression was increased at $15,30,45$ and 60 min with the stimulation
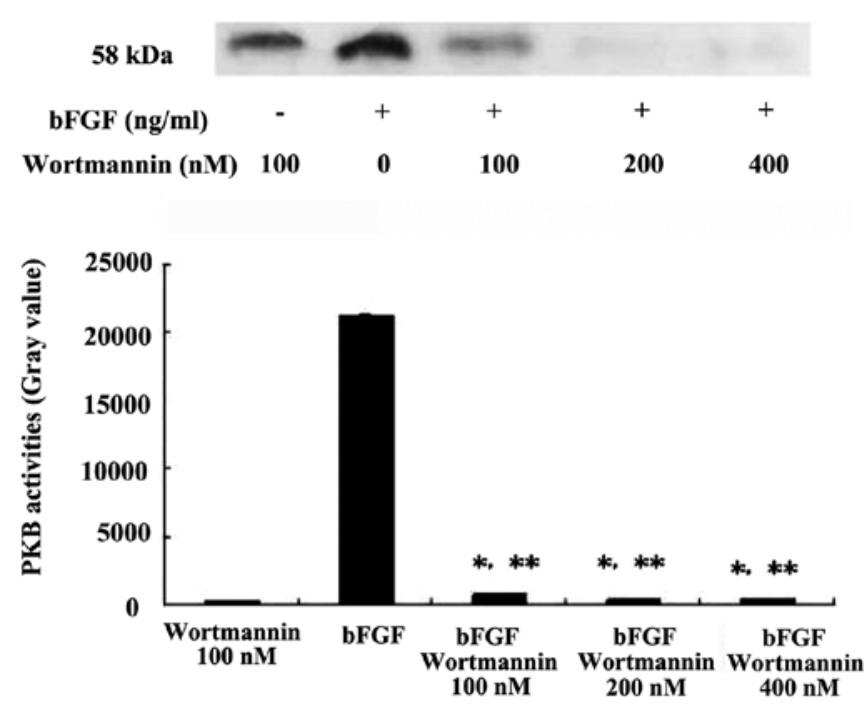

Figure 4. PKB activity after treatment with bFGF and wortmannin $(n=3$, mean $\pm \mathrm{SD})$. ${ }^{*}$ Compared with the wortmannin control group, $\mathrm{P}<0.05$ ${ }^{* *}$ Compared with the bFGF control group, $\mathrm{P}<0.01$.

bFGF $(10 \mathrm{ng} / \mathrm{ml}) \quad$ Wortmannin+bFGF $(10 \mathrm{ng} / \mathrm{ml})$

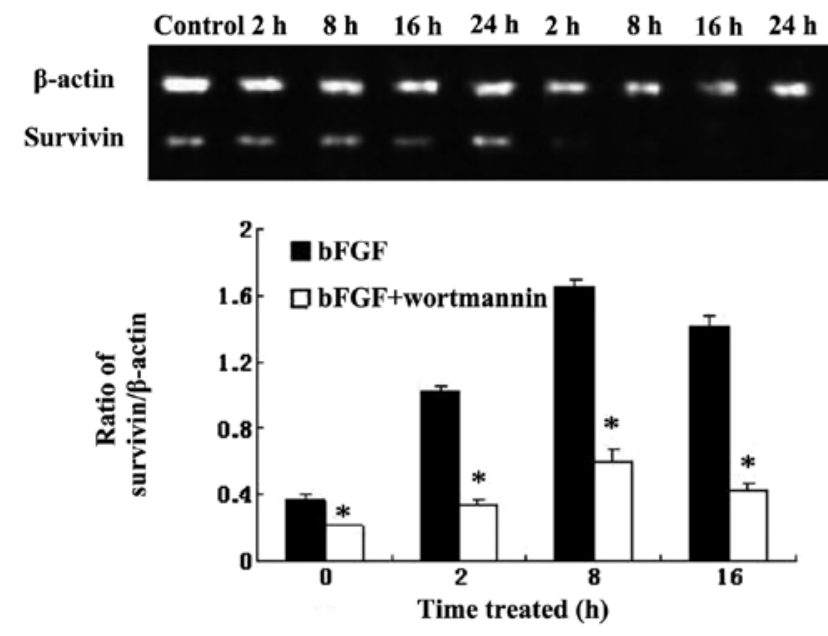

Figure 5. Expression of survivin mRNA in Bel-7402 cells treated with $10 \mathrm{ng} / \mathrm{ml}$ bFGF and wortmannin $(\mathrm{n}=3$, mean $\pm \mathrm{SD})$. ${ }^{*}$ Compared with the bFGF group, $\mathrm{P}<0.05$.

of $25 \mathrm{ng} / \mathrm{ml} \mathrm{bFGF}$, but PKB expression was clearly inhibited at each time-point when wortmannin $(200 \mathrm{nM})$ was added. The inhibition occurred in a time-dependent manner (Fig. 3). When pretreated with different concentrations of wortmannin under $25 \mathrm{ng} / \mathrm{ml} \mathrm{bFGF}$, the expression of PKB was inhibited significantly, in a dose-dependent manner, compared with the wortmannin control group $\mathrm{P}<0.05$, compared with the bFGF control group $\mathrm{P}<0.01$ (Fig. 4).

Survivin mRNA is upregulated with bFGF and downregulated with wortmannin. RT-PCR analysis showed that survivin mRNA expression of Bel-7402 cells was increased, and reached a peak at $16 \mathrm{~h}, 7.86$-fold upregulated compared with the control group after treatment with $10 \mathrm{ng} / \mathrm{ml}$ bFGF (Fig. 5) $(\mathrm{P}<0.05)$, which suggested that $\mathrm{bFGF}$ could induce the expression of survivin mRNA in liver cancer cells. While survivin 
A

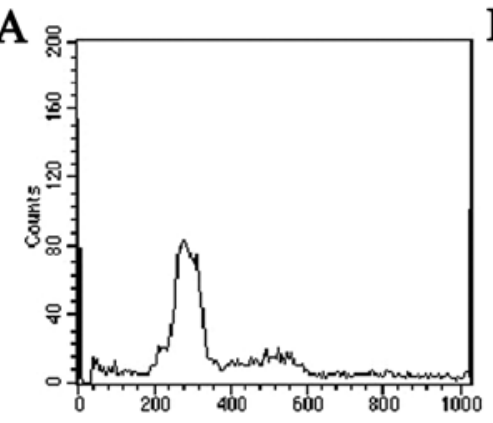

B

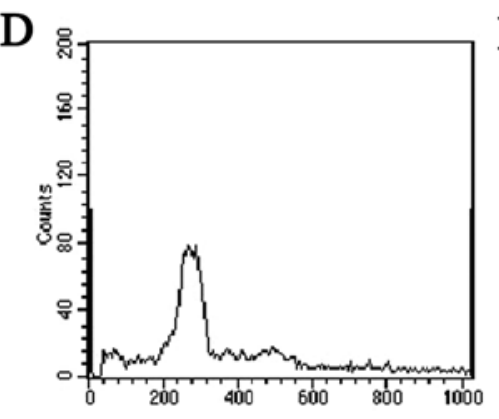

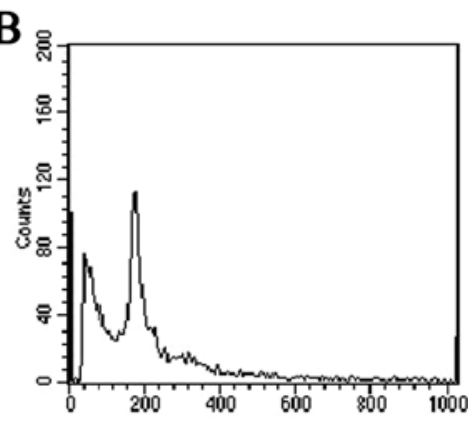
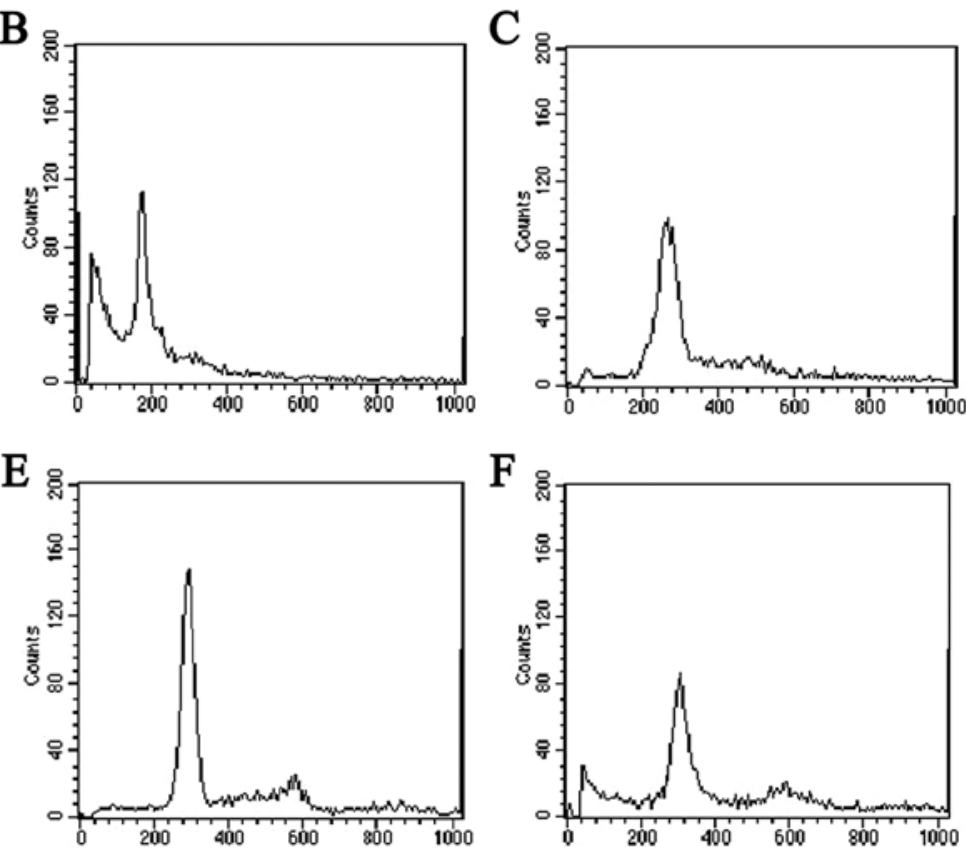

Figure 6. Quantitative detection of cell cycle and apoptotic Bel-7402 cells by flow cytometry.

mRNA expression was significantly suppressed by pretreatment with wortmannin $(200 \mathrm{nM})$ for $1 \mathrm{~h}, \mathrm{P}<0.05$, the highest inhibition occurred at $8 \mathrm{~h}$ (Fig. 5). The results suggested that increasing survivin mRNA expression induced by bFGF can be blocked by wortmannin in Bel-7402 cells.

bFGF and wortmannin are closely related to cell proliferation and apoptosis. The results of flow cytometry showed lower diploid peak and a small sub-G1 peak (apoptosis cells) in the Bel-7402 cell control group (Fig. 6A). Bel-7402 cells pretreated with wortmannin (200 nM, $1 \mathrm{~h})$ only showed significant hypodiploid peak, accompanied by a significant decline of $\mathrm{S}$ phase peak and apoptosis rate up to $50 \%$ compared with the cell control group, $\mathrm{P}<0.05$ (Fig. 6B). Following incubation with $25 \mathrm{ng} / \mathrm{ml} \mathrm{bFGF}$ for $10 \mathrm{~min}$, the apoptosis rate and $\mathrm{M}$ phase cells were apparently decreased, and $\mathrm{S}$ phase cells increased compared with the wortmannintreated group (Fig. 6C); however, no marked difference was detected compared with control cells. When this group was pretreated with wortmannin $(200 \mathrm{nM})$ for $1 \mathrm{~h}$, the apoptosis rate and $S$ phase increased significantly, $M$ phase cells decreased (Fig. 6D). Following treatment with $10 \mathrm{ng} / \mathrm{ml}$ bFGF for a longer time (16 h), Bel-7402 cells showed typical diploid peak, G1 phase cells increased and the apoptosis rate decreased significantly (Fig. 6E) compared with the control cell group $(\mathrm{P}<0.05$ vs. cell control and wortmannin-treated group), $\mathrm{S}$ phase cells increased clearly compared with the wortmannin-treated group. However, when this group was pretreated with wortmannin $(200 \mathrm{nM})$ for $1 \mathrm{~h}, \mathrm{G} 1$ phase cells decreased apparently, significant hypodiploid peak (subG1) appeared and the apoptosis rate increased significantly (Fig. 6F). The effects of bFGF and wortmannin on the apoptosis of Bel-7402 cells are also shown in Fig. 7, demonstrating that wortmannin induced high apoptosis rates and bFGF inhibited apoptosis induced by wortmannin.

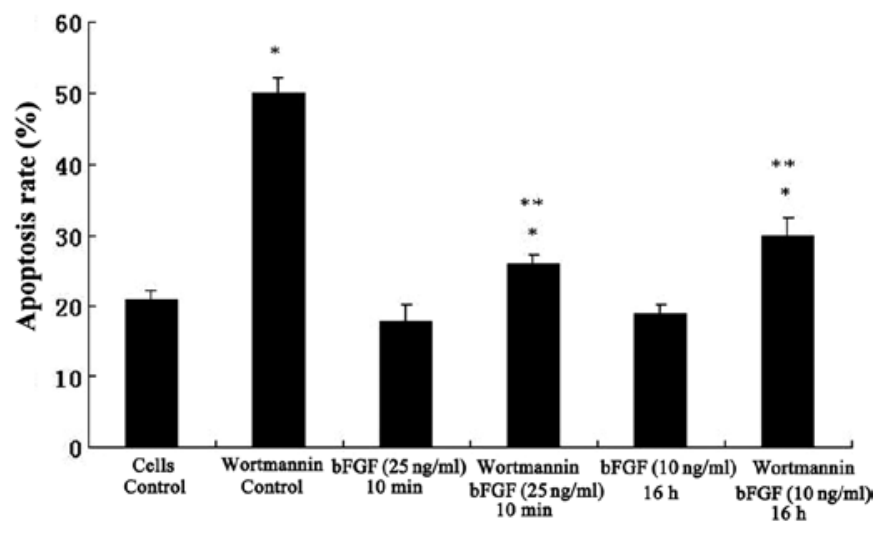

Figure 7. The effects of bFGF and wortmannin on the apoptosis of Bel-7402 cells $(n=3$, mean $\pm \mathrm{SD})$. ${ }^{*}$ Compared with the wortmannin control group, $\mathrm{P}<0.05$. ${ }^{* *}$ Compared with the bFGF control group, $\mathrm{P}<0.05$.

\section{Discussion}

The complex process of tumorigenesis in humans has been revealed to be a series of stochastic events which occur in almost all types of human cancer and involve the sequential acquisition of a number of genetic, epigenetic or somaticalterations as a result of increasing genomic instability $(26,27)$. Cancer cells launch various signaling pathways to respond to the altered external microenvironment and to coordinate cell growth with stress responses (28). High levels of TGF- $\beta$ and bFGF were found in a high percentage of human lung cancer tissues and have been associated with poor patient prognosis $(29,30)$. Although activation of the PBK signaling pathway by TGF- $\beta$ and bFGF is known to confer resistance to apoptosis in cancer cells, the exact mechanism by which this pathway regulates cell survival has yet to be elucidated. 
bFGF in the intracellular transduction pathway has previously been reported, but, to date, it is not fully understood. On the one hand, it can play a regulatory role by different intracellular transduction pathways, such as PLC/ PKC, PI3K/PKB, JAK/STAT (31-33). On the other hand, the role in regulating is not consistent in different cells; there is a negative regulatory role in certain cells (particularly tumor cells), while in other cells is the proliferation of the positive regulatory factors (34-36). PKB is the major downstream signal transduction pathway of PI3K. The effect of FGF on PKB activity has yet to be clarified. Although the point that $\mathrm{PKB}$ activation is required for cell cycle progression remains to be confirmed, studies show that PKB in some downstream target substances can directly influence cell cycle progression.

It has been reported that survivin inhibits apoptosis by suppressing caspase- 3 and caspase- 7 and modulates the $\mathrm{G} 2 / \mathrm{M}$ phase of the cell cycle through association with mitotic spindle microtubules (18). Cytokines and intracellular growth signal transduction can regulate the expression of survivin. To examine whether bFGF can activate PKB and survivin via the PI3K pathway in the hepatoma cell line Bel-7402, we observed the changes of cytoplasmic PKB and survivin mRNA expression in the Bel-7402 cells with bFGF stimulation and PI3K pathway inhibitor wortmannin. The results showed that the expression of PKB and survivin significantly increased with bFGF (10-25 ng/ml) treatment. These effects were clearly inhibited by pretreatment with wortmannin $(200 \mathrm{nM})$. bFGF treatment inhibited the apoptosis rate of Bel-7402 cells and decreased G2/M phase of the cell cycle, while this effect was blocked by pretreatment with wortmannin $(200 \mathrm{nM})$ for $1 \mathrm{~h}$. The results showed that wortmannin could induce high apoptosis and bFGF could inhibit apoptosis induced by wortmannin. The results revealed that bFGF could rapidly activate the PKB activities, enhance the expression of survivin and the proliferation of hepatocarcinoma cells via the PI3K pathway, thus it may be a novel molecule for early targeting therapy of hepatocarcinoma.

The ability of bFGF to inhibit apoptosis and promote survival of cells could be explained by the following pathways: first, upregulation of Bcl-2 (37-39); secondly, P13 kinase-Akt/ PKB signaling pathway which is further confirmed by our results $(37,40)$; the third, upregulation of at least two members of the IAP gene family, XIAP and survivin. For the third pathway, our results showed approximately 8-fold upregulation of survivin induced by bFGF, while PKB was upregulated approximately 3 -fold under the same conditions. Previous studies suggested that human survivin, while absent in most adult differentiated tissues, could be detected in almost all transformed cell lines and types of cancer, as well as in fetal tissue (23). Thus, survivin behaves as an 'oncofetal' protein. Our results therefore suggest that therapeutically targeting survivin at the gene expression or protein expression/function levels may result in suppression of angiogenesis. It is also notable that the cell cycle dependency of bFGF induced upregulation of survivin expression. Li et al suggested that survivin may counteract a default induction of apoptosis in the $\mathrm{G} 2 / \mathrm{M}$ phase by associating with the mitotic spindle at the beginning of mitosis (41). It could be hypothesized that the bFGF functions in survival and mitogenesis of endothelial cells may not be mutually exclusive. Indeed, survivin may be upregulated at the $\mathrm{G} 2 / \mathrm{M}$ interface in order to counteract an apoptotic signal, thereby allowing liver cells to survive cell cycle progression and to finally proceed to mitosis. This could therefore represent a tighter association between the mitotic and survival functions. Based on these results, it is also of interest to determine whether agents which block bFGF, or bFGF receptor function, inhibit angiogenesis, in part, by the simultaneous downregulation of multiple effectors of cell survival such as survivin and XIAP. Furthermore, certain other antiangiogenic agents or regulators which are known to induce cell apoptosis, e.g., tubulin-binding agents such as combretastatin-A4, or endogenous inhibitors of angiogenesis, such as angiopoietin-2, may do so, at least in part, by interfering with the survival functions of IAP proteins such as survivin and XIAP expressed by such cells.

Promoting proliferation is one of the main functions of bFGF. Survivin is currently the strongest known inhibitor of apoptosis inhibitory proteins. Our results revealed the correlation of both signaling pathways. The result is consistent with the functionality of bFGF and survivin. Following pretreatment with PI3K inhibitor wortmannin, and then bFGF treatment, cell proliferation was inhibited, survivin mRNA expression levels correspondingly decreased, suggesting that bFGF affects the expression of survivin PKB signaling pathway, which regulates cell proliferation and apoptosis.

Emerging data indicate a pivotal role for IAP family members in maintaining cancer cell survival and inhibiting apoptosis induced by anticancer drugs. Our data provide further validation of IAP family members as potential drug discovery targets for the improved treatment of liver cancer. The association between bFGF, survivin and hepatoma cancer warrants further investigation.

\section{References}

1. Hu M and Polyak K: Microenvironmental regulation of cancer development. Curr Opin Genet Dev 18: 27-34, 2008.

2. Bissell MJ and Radisky D: Putting tumours in context. Nat Rev Cancer 1: 46-54, 2001.

3. Radisky D, Hagios C and Bissell MJ: Tumors are unique organs defined by abnormal signaling and context. Semin Cancer Biol 11: 87-95, 2001.

4. Klagsbrun M and Soker S: VEGF/VPF: The angiogenesis factor found? Curr Biol 3: 699-702, 1993

5. Neufeld G, Cohen T, Gengrinovitch S and Poltorak Z: Vascular endothelial growth factor (VEGF) and its receptors. FASEB J 13: 9-22, 1999.

6. Tran J, Rak J, Sheehan C, et al: Marked induction of the IAP family antiapoptotic proteins survivin and XIAP by VEGF in vascular endothelial cells. Biochem Biophys Res Commun 264: 781-788, 1999.

7. Ouyang G, Liu M, Ruan K, et al: Upregulated expression of periostin by hypoxia in non-small-cell lung cancer cells promotes cell survival via the Akt/PKB pathway. Cancer Lett 281: 213-219, 2009.

8. Zhang L, Bhojani MS, Ross BD and Rehemtulla A: Molecular imaging of protein kinases. Cell Cycle 7: 314-317, 2008.

9. Zhang L, Lee KC, Bhojani MS, et al: Molecular imaging of Akt kinase activity. Nat Med 13: 1114-1119, 2007.

10. Kunkel MT, Ni Q, Tsien RY, Zhang J and Newton AC: Spatiotemporal dynamics of protein kinase B/Akt signaling revealed by a genetically encoded fluorescent reporter. J Biol Chem 280: 5581-5587, 2005

11. Harvey RD and Lonial S: PI3 kinase/AKT pathway as a therapeutic target in multiple myeloma. Future Oncol 3: 639-647, 2007. 
12. Yang L, Dan HC, Sun M, et al: Akt/protein kinase B signaling inhibitor-2, a selective small molecule inhibitor of Akt signaling with antitumor activity in cancer cells overexpressing Akt. Cancer Res 64: 4394-4399, 2004.

13. Skrzypski M, Kaczmarek P and Le TT: Effects of orexin A on proliferation, survival, apoptosis and differentiation of 3T3-L1 preadipocytes into mature adipocytes. FEBS Lett 586: 4157-4164, 2012

14. Jin P, Wang YH, Peng YG, Hu S, Lu Q and Yang LY: Effect of PI3K/AKT inhibitor on benign prostate hyperplasia and its mechanism: an experimental study. Zhonghua Nan Ke Xue 16: 1068-1075, 2010 (In Chinese).

15. Zhang HJ, Siu MK, Yeung MC, et al: Overexpressed PAK4 promotes proliferation, migration and invasion of choriocarcinoma. Carcinogenesis 32: 765-771, 2011.

16. Yang Q, Liu HY, Zhang YW, et al: Anandamide induces cell death through lipid rafts in hepatic stellate cells. J Gastroenterol Hepatol 25: 991-1001, 2010.

17. Altieri DC and Marchisio C: Survivin apoptosis: an interloper between cell death and cell proliferation in cancer. Lab Invest 79: $1327-1333,1999$

18. Yamamoto $\mathrm{T}$ and Tanigawa $\mathrm{N}$ : The role of survivin as a new target of diagnosis and treatment in human cancer. Med Electron Microsc 34: 207-212, 2001.

19. Tamm I, Want Y, Sausville E, et al: IAP-family protein survivin inhibits caspase activity and apoptosis induced by Fas (CD95), Bax, caspases, and anticancer drugs. Cancer Res 58: 5315-5320, 1998.

20. Altieri DC: Survivin versatile modulation of cell division and apoptosis in cancer. Oncogene 22: 8581-8589, 2003.

21. Kajiwara Y, Yamasaki F, Hama S, et al: Exression of survivin in astrocytic tumors: correlation with malignant grade and prognosis. Cancer 97: 1077-1083, 2003.

22. Islam A, Kageyama $\mathrm{H}$, Takada $\mathrm{N}$, et al: High expression of survivin, mapped to $17 \mathrm{q} 25$, is significantly associated with poor prognostic factors and promotes cell survival in human neuroblastoma. Oncogene 19: 617-623, 2000.

23. Ambrosini G, Adida C and Altieri D: A novel anti-apoptosis gene, survivin, expressed in cancer and lymphoma. Nat Med 3: 917-921, 1997.

24. Ngan CY, Yamamoto H, Takagi A, et al: Oxaliplatin induces mitotic catastrophe and apoptosis in esophageal cancer cells. Cancer Sci 99: 129-139, 2008.

25. Huang CK, Lee SO, Lai KP, et al: Targeting androgen receptor in bone marrow mesenchymal stem cells leads to better transplantation therapy efficacy in liver cirrhosis. Hepatology 57: $1550-1563,2013$.

26. Hanahan D and Weinberg RA: The hallmarks of cancer. Cell 100: 57-70, 2000.

27. Hahn WC and Weinberg RA: Modelling the molecular circuitry of cancer. Nat Rev Cancer 2: 331-341, 2002.

28. López-Maury L, Marguerat S and Bähler J: Tuning gene expression to changing environments: from rapid responses to evolutionary adaptation. Nat Rev Genet 9: 583-593, 2008.
29. Tateishi M, Ishida T, Mitsudomi T, Kaneko S and Sugimachi K: Immunohistochemical evidence of autocrine growth factors in adenocarcinoma of the human lung. Cancer Res 50: 7077-7080, 1990.

30. Brattstrom D, Bergqvist M, Hesselius P, Larsson A, Wagenius G and Brodin O: Serum VEGF and bFGF adds prognostic information in patients with normal platelet counts when sampled before, during and after treatment for locally advanced non-small cell lung cancer. Lung Cancer 43: 55-62, 2004.

31. Sufen G, Xianghong Y, Yongxia $C$ and Qian P: bFGF and PDGF-BB have a synergistic effect on the proliferation, migration and VEGF release of endothelial progenitor cells. Cell Biol Int 35: 545-551, 2011.

32. Drevs J, Zirrgiebel U and Schmidt-Gersbach CI: Soluble markers for the assessment of biological activity with PTK787/ZK 222584 (PTK/ZK), a vascular endothelial growth factor receptor (VEGFR) tyrosine kinase inhibitor in patients with advanced colorectal cancer from two phase I trials. Ann Oncol 16: 558-565, 2005.

33. Feng X, Zhang B, Wang J, et al: Adenovirus-mediated transfer of siRNA against basic fibroblast growth factor mRNA enhances the sensitivity of glioblastoma cells to chemotherapy. Med Oncol 28: 24-30, 2011.

34. Wang H, Rubin M, Fenig E, et al: Basic fibroblast growth factor causes growth arrest in MCF-7 human breast cancer cells while inducing both mitogenic and inhibitory G1 events. Cancer Res 57: 1750-1757, 1997.

35. Shankland SJ, Pippin J, Flanagan M, et al: Mesangial cell proliferation mediated by PDGF and bFGF is determined by levels of the cyclin kinase inhibitor p27Kip1. Kidney Int 51: 1088-1099, 1997.

36. Johnson MR, Valentine C, Basilio C and Mansukhani A: FGF signaling activates STAT1 and $\mathrm{p} 21$ and inhibits the estrogen response and proliferation of MCF-7 cells. Oncogene 16: 2647-2656, 1998 .

37. Carmeliet P, Lampugnani MG, Moons L, et al: Targeted deficiency or cytosolic truncation of the VE-cadherin gene in mice impairs VEGF-mediated endothelial survival and angiogenesis. Cell 98: 147-157, 1999.

38. Kim JW, Ho WJ and Wu BM: The role of the 3D environment in hypoxia-induced drug and apoptosis resistance. Anticancer Res 31: 3237-3245, 2011

39. Gerber HP, Dixit V and Ferrara N: Vascular endothelial growth factor induces expression of the antiapoptotic proteins Bcl-2 and A1 in vascular endothelial cells. J Biol Chem 273: 13313-13316, 1998.

40. Gerber HP, McMurtrey A, Kowalski J, Yan M, Keyt BA, Dixit V and Ferrara N: Vascular endothelial growth factor regulates endothelial cell survival through the phosphatidylinositol 3'-kinase/ Akt signal transduction pathway. Requirement for Flk-1/KDR activation. J Biol Chem 273: 30336-30343, 1998.

41. Li F, Ambrosini G, Chu EY, Plescia J, et al: Control of apoptosis and mitotic spindle checkpoint by survivin. Nature 396: 580-584, 1998. 